\title{
Soil microbial nutrient constraints along a tropical forest elevation gradient: a belowground test of a biogeochemical paradigm
}

\author{
A. T. Nottingham ${ }^{1}$, B. L. Turner ${ }^{2}$, J. Whitaker ${ }^{3}$, N. J. Ostle ${ }^{4}$, N. P. McNamara ${ }^{3}$, R. D. Bardgett ${ }^{5}$, N. Salinas B, $^{6,8}$, and \\ P. Meir ${ }^{1,9}$ \\ ${ }^{1}$ School of Geosciences, University of Edinburgh, Drummond Street, Edinburgh, EH8 9XP, UK \\ ${ }^{2}$ Smithsonian Tropical Research Institute, Apartado 0843-03092, Balboa, Ancon, Republic of Panama \\ ${ }^{3}$ Centre for Ecology \& Hydrology, Lancaster Environment Centre, Library Avenue, Lancaster, LA1 4AP, UK \\ ${ }^{4}$ Lancaster Environment Centre, Lancaster University, Bailrigg, Lancaster, LA1 4YQ, UK \\ ${ }^{5}$ Faculty of Life Sciences, Michael Smith Building, The University of Manchester, Oxford Road, Manchester, M13 9PT, UK \\ ${ }^{6}$ Seccion Química, Pontificia Universidad Católica del Peru, Lima, Peru \\ ${ }^{7}$ Universidad Nacional de San Antonio Abad del Cusco, Facultad de Biología, Cusco, Peru \\ ${ }^{8}$ Environmental Change Institute, School of Geography and the Environment, South Parks Road, Oxford, OX1 3QY, UK \\ ${ }^{9}$ Research School of Biology, Australian National University, Canberra, ACT 0200, Australia
}

Correspondence to: A. T. Nottingham (anotting@staffmail.ed.ac.uk)

Received: 26 February 2015 - Published in Biogeosciences Discuss.: 30 April 2015

Revised: 19 August 2015 - Accepted: 19 August 2015 - Published: 26 October 2015

\begin{abstract}
Aboveground primary productivity is widely considered to be limited by phosphorus $(\mathrm{P})$ availability in lowland tropical forests and by nitrogen $(\mathrm{N})$ availability in montane tropical forests. However, the extent to which this paradigm applies to belowground processes remains unresolved. We measured indices of soil microbial nutrient status in lowland, sub-montane and montane tropical forests along a natural gradient spanning $3400 \mathrm{~m}$ in elevation in the Peruvian Andes. With increasing elevation there were marked increases in soil concentrations of total $\mathrm{N}$, total $\mathrm{P}$, and readily exchangeable $\mathrm{P}$, but a decrease in $\mathrm{N}$ mineralization determined by in situ resin bags. Microbial carbon (C) and $\mathrm{N}$ increased with increasing elevation, but microbial $\mathrm{C}: \mathrm{N}: \mathrm{P}$ ratios were relatively constant, suggesting homeostasis. The activity of hydrolytic enzymes, which are rich in $\mathrm{N}$, decreased with increasing elevation, while the ratio of enzymes involved in the acquisition of $\mathrm{N}$ and $\mathrm{P}$ increased with increasing elevation, further indicating an increase in the relative demand for $\mathrm{N}$ compared to $\mathrm{P}$ with increasing elevation. We conclude that soil microorganisms shift investment in nutrient acquisition from $\mathrm{P}$ to $\mathrm{N}$ between lowland and montane tropical forests, suggesting that different nutrients regulate soil microbial metabolism and the soil carbon balance in these ecosystems.
\end{abstract}

\section{Introduction}

Tropical forests have a major influence on the global carbon (C) cycle, being the most productive ecosystems on Earth and containing $34-55 \%$ of the $\mathrm{C}$ in forests worldwide (Beer et al., 2010; Pan et al., 2011). The exchange of $C$ between the atmosphere and forests is mediated by the availability of mineral nutrients, so there is widespread interest in understanding how plant or microbial metabolic processes are constrained by the deficiencies of specific "limiting" nutrients (Cleveland et al., 2011; Wright et al., 2011), and how human alteration of these nutrient cycles may impact tropical ecosystems (Hietz et al., 2011; Townsend et al., 2011). Our understanding of nutrient limitation in the tropical forest $\mathrm{C}$ cycle is based largely on the responses of aboveground production. In contrast, belowground processes remain relatively under-studied, despite evidence that they are limited by different nutrients to those limiting aboveground productivity in some ecosystems, including tropical forests (Sundareshwar et al., 2003; Turner and Wright, 2014). It is important to identify nutrient constraints to soil microbial process in tropical forests to understand how anthropogenic alteration of biogeochemical cycles will impact $\mathrm{C}$ storage in these ecosystems. 
Primary productivity is commonly constrained by nitrogen (N) and phosphorus (P) availability in ecosystems globally (Elser et al., 2007). In lowland tropical forests, primary productivity is widely considered to be limited by $\mathrm{P}$ availability (Reed et al., 2011; Vitousek et al., 2010), in part because lowland forests are dominated by strongly weathered soils that contain low concentrations of biologically available $\mathrm{P}$ and high apparent $\mathrm{N}$ availability (Hedin et al., 2009; Reed et al., 2011). In contrast, primary productivity in tropical montane forests is often considered to be limited by the availability of $\mathrm{N}$ rather than $\mathrm{P}$ (Tanner et al., 1998). This is because soil $\mathrm{P}$ depletion in montane environments is countered by the actions of tectonic uplift, erosion and landslide activity (Porder and Hilley, 2010), while $\mathrm{N}$ inputs via litter mineralization and biological $\mathrm{N}$ fixation can be reduced by low temperatures and fewer legumes (Bruijnzeel et al., 2011). Overall, these processes appear to reinforce the pattern of $\mathrm{P}$ deficiency in lowland forests and $\mathrm{N}$ deficiency in montane tropical ecosystems.

The notion that there is switch from predominantly $\mathrm{P}$ to $\mathrm{N}$ limitation of primary productivity between lowland and montane tropical forests is supported by experimental studies in forest communities (Tanner et al., 1998). Also, the widespread existence of $\mathrm{P}$ limitation of primary production in lowland tropical forests (Hedin et al., 2009; Vitousek and Sanford, 1986) is supported by studies in which P fertilization increased the growth of trees and seedlings (AlvarezClare et al., 2013) and increased litter production (Mirmanto et al., 1999; Wright et al., 2011). However, co-limitation by $\mathrm{N}, \mathrm{P}$ and $\mathrm{K}$ of seedling and sapling growth (Santiago et al., 2012; Wright et al., 2011) and $\mathrm{N}$ and P co-limitation of tree growth (Fisher et al., 2013) have also been reported. In contrast, aboveground productivity in montane forests appears to be constrained primarily by $\mathrm{N}$, based on responses to $\mathrm{N}$ fertilization in growth rates and litter production (Fisher et al., 2013; Tanner et al., 1992).

It remains unclear if the pattern of nutrient limitation in montane and lowland forests holds for belowground organisms as it does for plants. The activity of heterotrophic soil microbes is primarily limited by the availability of labile $\mathrm{C}$, but $\mathrm{N}$ and $\mathrm{P}$ exert important constraints (Wardle, 1992). In lowland tropical forests, there is evidence to suggest that $\mathrm{P}$ limits microbial growth (Turner and Wright, 2014) and microbial $\mathrm{C}$ mineralization during decomposition (Cleveland et al., 2006; Kaspari et al., 2008), although other nutrients can also limit soil microbial processes (Hattenschwiler et al., 2011; Kaspari et al., 2009; Waring, 2012). In contrast, studies in tropical montane forest have shown a stimulation of soil microbial biomass or respiration by $\mathrm{N}$ fertilization (Corre et al., 2010; Cusack et al., 2011b; Fisher et al., 2013; Li et al., 2006), although conclusions remain tentative because many of these montane forest experiments included $\mathrm{N}$ additions but not $\mathrm{P}$ or K. For example, high phosphatase activity in one of these studies suggests potential $\mathrm{P}$ limitation of the microbial community in a lower montane forest (Cusack et al., 2011b).
We therefore lack conclusive evidence to demonstrate the extent to which soil microbial processes are constrained by nutrients across gradients of tropical lowland and montane forests.

Soil microbial nutrient limitation is often experimentally defined as a response of microbial growth, metabolism or respiration to nutrient addition (e.g. Cleveland et al., 2006; $\mathrm{Cu}-$ sack et al., 2011b; Turner and Wright, 2014). However, the establishment of fertilization experiments at multiple sites and across large environmental gradients is challenging. An alternative approach, more easily replicated across multiple sites, is the indirect assessment of nutrient limitation by measuring the stoichiometry of nutrients in organisms (Vitousek et al., 2010). Nutrient limitation of plant growth in tropical forests has, for example, been inferred from measurements of nutrient stoichiometry in fresh leaves and litterfall (McGroddy et al., 2004; Vitousek and Sanford, 1986). Elemental stoichiometry can similarly be used to indirectly assess nutrient limitation on microbial $\mathrm{C}$ metabolism by evaluating the stoichiometry of nutrients in the soil microbial biomass (Cleveland and Liptzin, 2007). The consistent amounts of $\mathrm{N}$ and $\mathrm{P}$ required to build and maintain different cellular structures gives rise to the hypothesis that, under optimal growth conditions, the $\mathrm{C}: \mathrm{N}: \mathrm{P}$ ratio in organisms is constrained, while a limiting resource supply will be reflected in an altered C: N : P ratio (Elser et al., 2003; Redfield, 1958). Elemental stoichiometry within organisms can indicate a growth limiting resource, provided that the elemental composition of the organism is non-homeostatic (passive regulation; elemental composition reflects resource availability) rather than homeostatic (active regulation; fixed elemental composition; Sterner and Elser, 2002).

The stoichiometry of enzyme activities can provide further indirect evidence of nutrient limitations to microbial $\mathrm{C}$ metabolism by indicating investment in resource acquisition (Sinsabaugh et al., 2008). The activities of enzymes involved in nutrient degradation indicate the allocation of microbial resources to the acquisition of specific nutrients, which is often in response to a deficiency of the mineral form of that nutrient (Allison et al., 2010; Sinsabaugh and Moorhead, 1994). For example, deficiencies in soil $\mathrm{N}$ or $\mathrm{P}$ are reflected by higher activity of $N$-acetyl $\beta$-glucosaminidase or phosphomonoesterase, respectively (Allison et al., 2007; Olander and Vitousek, 2000; Sinsabaugh and Moorhead, 1994; Treseder and Vitousek, 2001). A deficiency in soil N can also reduce the activity of enzymes in general, because proteins are rich in N (Allison and Vitousek, 2005; Allison et al., 2010). The activity and stoichiometry of nutrient-degrading enzymes can therefore indicate the relative strength and nature of microbial nutrient demand.

We tested the hypothesis that the nutrient status of the soil microbial biomass switches from greater relative demand for $\mathrm{P}$ in lowland tropical forest to greater relative demand for $\mathrm{N}$ in montane tropical forest. To do this, we measured soil nutrient availability, soil microbial nutrient stoichiometry, and the 
activity and stoichiometry of soil enzymes along a $3400 \mathrm{~m}$ elevation gradient under tropical forest in the Peruvian Andes. We estimated microbial nutrient status using three approaches. First, we determined soil $\mathrm{N}$ and $\mathrm{P}$ availability along the gradient. Second, we assessed relative differences in the stoichiometry of $\mathrm{C}, \mathrm{N}$ and $\mathrm{P}$ in the microbial biomass, whereby a greater C-to-nutrient ratio indicates increased limitation on microbial growth. Third, we determined the relative differences in the stoichiometry of enzymes involved in the degradation of $\mathrm{C}, \mathrm{N}$ and $\mathrm{P}$, whereby a decreased C-tonutrient enzymatic ratio indicates increased nutrient limitation on microbial metabolism and microbial investment in enzymes for acquisition of that nutrient. This approach allowed indirect assessment of microbial nutrient limitation across a large geographic gradient, but was limited by the assumption that nutrient limitation on microbial growth and metabolism is the sole constraint on elemental stoichiometry in the microbial biomass (assuming non-homeostasis) and on the stoichiometry of enzyme activities. We hypothesized that increasing $\mathrm{P}$ availability and decreasing $\mathrm{N}$ availability with increasing elevation would lead to changes in indicators of microbial nutrient stress, including (1) increased concentrations of extractable inorganic phosphate, but decreased concentrations of $\mathrm{N}$ turnover; (2) decreased $\mathrm{N}: \mathrm{P}$ ratio in the soil microbial biomass; (3) increased activity of enzymes involved in the degradation of compounds containing $\mathrm{N}$ relative to $\mathrm{P}$ (increased N : P enzymatic ratio); and (4) decreased activities of all enzymes (indicating increasing $\mathrm{N}$ limitation).

\section{Methods}

\subsection{Study sites}

We used thirteen study sites situated along an elevation gradient on the eastern flank of the Peruvian Andes (Nottingham et al., 2015). The sites range in elevation from 194 to $3400 \mathrm{~m}$ a.s.l. (above sea level) and have continuous forest cover, which ranges from lowland Amazonian rainforest to upper montane cloud forest. The transect from 1000 to $3400 \mathrm{~m}$ a.s.l. is $35 \mathrm{~km}$ in length and the two lowland sites are a further $230 \mathrm{~km}$ down the valley. Mean annual temperature decreases with increasing elevation $\left(26\right.$ to $\left.8^{\circ} \mathrm{C}\right)$ and mean annual precipitation ranges from 1560 to $5302 \mathrm{~mm} \mathrm{yr}^{-1}$. Although mean annual precipitation does not vary linearly with elevation, with some inter-annual variability indicated by a range of reported values (the most recent indicate a peak at mid-elevation; Malhi, unpublished date; Table 1), evidence to date indicates that soils at all sites are rarely moisture limited over the seasonal cycle (van de Weg et al., 2014; van de Weg et al., 2009; Zimmermann et al., 2010).

The sites are situated predominantly on Paleozoic ( $\sim 450 \mathrm{Ma}$ ) meta-sedimentary mudstones, with plutonic intrusions (granite) underlying the sites between 1500 and 2020 m a.s.l. (Carlotto et al., 1996; Clark et al., 2013). The soils at sites above $2520 \mathrm{~m}$ have been classified as Umbrisols according to FAO World Reference Base classification (Inceptisols according to USDA Soil Taxonomy). In contrast, the soils from 1000 to $2020 \mathrm{~m}$ have been classified as Cambisols (Inceptisols) and the soils at the two lowland sites have been classified as Haplic Alisols (Ultisols; 194 m a.s.l.) and Haplic Cambisols (Inceptisols; $210 \mathrm{~m}$ a.s.l.; Quesada et al., 2010). The soils at higher elevations are shallower and have a deeper organic layer (e.g. $22.8 \mathrm{~cm}$ at the $3030 \mathrm{~m}$ a.s.l. site compared to $0.7 \mathrm{~cm}$ at the $194 \mathrm{~m}$ a.s.l. site; Table 1). Further descriptions of the soils (Quesada et al., 2010; Whitaker et al., 2014), climate (Rapp and Silman, 2012), aboveground productivity and floristic composition (Asner et al., 2014; Feeley et al., 2011; Girardin et al., 2010) are reported elsewhere.

\subsection{Soil sampling and analyses for total nutrients}

Soils were sampled in December 2010 from five systematically distributed sub-plots within a 1 ha permanent sample plot at each study site at a standardized $0-10 \mathrm{~cm}$ depth. For each sub-plot, soil was removed from a $40 \times 40 \mathrm{~cm}$ area. Soils were sealed in plastic bags and stored at $4{ }^{\circ} \mathrm{C}$ for up to 4 weeks until analysis. Given that temperature does not seasonally vary in our study sites, any seasonal variation in our measured soil and microbial properties would most likely be driven by seasonality of rainfall (Turner and Wright, 2014). However, December is in the rainy season for all of these sites (Rapp and Silman, 2012); therefore, our assessments were made during a relatively constant period of active decomposition when moisture was not limiting. Furthermore, soil moisture measurements have shown that none of the sites appear to suffer from significant seasonal moisture stress (Zimmermann et al., 2010), suggesting that our sampling is representative of the prevailing conditions at other times of the year.

Total $\mathrm{C}$ and $\mathrm{N}$ were determined on dried (at $105^{\circ} \mathrm{C}$ ) and ground soil samples using a TruSpec CN Elemental Analyzer (LECO, USA). Total $\mathrm{P}$ was determined by ignition $\left(550^{\circ} \mathrm{C}\right.$, $1 \mathrm{~h}$ ) followed by extraction in $1 \mathrm{M} \mathrm{H}_{2} \mathrm{SO}_{4}$, with phosphate detection in neutralized extracts at $880 \mathrm{~nm}$ by automated molybdate colorimetry using a Lachat Quikchem 8500 (Hach Ltd, Loveland, CO). Soil $\mathrm{pH}$ was determined in water in a $1: 2$ soil to solution ratio using a calibrated glass electrode. Bulk density was determined by drying a known volume of soil (taken in a cylinder) for $24 \mathrm{~h}$ at $105^{\circ} \mathrm{C}$ to constant mass. Gravimetric moisture content at the time of sampling and water holding capacity (in saturated soils) were calculated according to the amount of water remaining in the soil after being left to drain for $12 \mathrm{~h}$ (Whitaker et al., 2014).

\subsection{Microbial biomass and extractable nutrients}

Soil microbial biomass $\mathrm{C}$ and $\mathrm{N}$ were measured by fumigation-extraction (Brookes et al., 1985; Vance et al., 
Table 1. Summary of site characteristics along the elevation gradient, spanning lowland rainforest (194-210 ma.s.1.), pre-montane (1000 m a.s.1.), lower montane (1500-2020 m a.s.1.) and upper montane cloud forest (2520-3400 m a.s.1.; Aragao et al., 2009; Asner et al., 2014; Girardin et al., 2010; Malhi, unpublished data; Quesada et al., 2010). NA is data not available.

\begin{tabular}{|c|c|c|c|c|c|c|c|c|c|c|c|}
\hline Site name & Site code & $\begin{array}{r}\text { Elevation } \\
\text { (ma.s.1.) }\end{array}$ & Lat & Long & $\begin{array}{r}\text { Mean annual } \\
\text { temp }\left({ }^{\circ} \mathrm{C}\right)\end{array}$ & $\begin{array}{r}\text { Annual } \\
\text { precipitation } \\
\left(\mathrm{mm} \mathrm{yr}^{-1}\right)\end{array}$ & $\begin{array}{r}\text { Soil organic } \\
\text { horizon } \\
(\mathrm{cm})\end{array}$ & $\begin{array}{r}\text { Aspect } \\
(\text { deg) }\end{array}$ & $\begin{array}{l}\text { Slope } \\
(\text { deg })\end{array}$ & $\begin{array}{l}\text { Parent } \\
\text { material }\end{array}$ & $\begin{array}{l}\text { Soil } \\
\text { classification }\end{array}$ \\
\hline $\begin{array}{l}\text { Explorer's Inn } \\
\text { plot } 4 \text { (TP4) }\end{array}$ & TAM-06 & 194 & -12.839 & -69.296 & 26.4 & $1900-2730$ & 1 & 169.4 & 4 & $\begin{array}{l}\text { Holocene alluvial } \\
\text { terrace }\end{array}$ & Haplic Alisol \\
\hline $\begin{array}{l}\text { Explorer's Inn } \\
\text { plot } 3 \text { (TP3) }\end{array}$ & TAM-05 & 210 & -12.830 & -69.271 & 26.4 & $1900-3199$ & 2 & 186.2 & 6.9 & $\begin{array}{l}\text { Pleistocene alluvial } \\
\text { terrace }\end{array}$ & Haplic Cambisol \\
\hline Villa Carmen & $\mathrm{VC}$ & 1000 & -12.866 & -71.401 & 20.7 & 3087 & 4 & NA & NA & NA & NA \\
\hline San Pedro 2 & SPD-2 & 1500 & -13.049 & -71.537 & 17.4 & $2631-5302$ & 16 & 143.5 & 39 & Plutonic intrusion (granite) & Cambisol \\
\hline Trocha Union 8 & TRU-08 & 1850 & -13.071 & -71.555 & 16.0 & 2472 & 16 & 137.0 & 41.8 & Plutonic intrusion (granite) & Cambisol \\
\hline Trocha Union 7 & TRU-07 & 2020 & -13.074 & -71.559 & 14.9 & 1827 & 17 & NA & NA & $\begin{array}{l}\text { Paleozoic shales-slates/ } \\
\text { Granite intrusion }\end{array}$ & Cambisol \\
\hline Trocha Union 5 & TRU-05 & 2520 & -13.094 & -71.574 & 12.1 & NA & 14 & NA & NA & Paleozoic shales-slates & NA \\
\hline Trocha Union 4 & TRU-04 & 2720 & -13.107 & -71.589 & 11.1 & $2318-2678$ & 21 & 189.8 & 28.6 & Paleozoic shales-slates & Umbrisol \\
\hline Trocha Union 3 & TRU-03 & 3020 & -13.109 & -71.600 & 9.5 & $1776-2678$ & 17 & 129.3 & 37.6 & Paleozoic shales-slates & Umbrisol \\
\hline Wayqecha & WAY-01 & 3025 & -13.190 & -71.587 & 11.1 & $1560-1706$ & 23 & NA & NA & Paleozoic shales-slates & Umbrisol \\
\hline Trocha Union 2 & TRU-02 & 3200 & -13.111 & -71.604 & 8.9 & NA & 12 & NA & NA & Paleozoic shales-slates & Umbrisol \\
\hline Trocha Union 1 & TRU-01 & 3400 & -13.114 & -71.607 & 7.7 & 2555 & 14 & 144.3 & 34.3 & Paleozoic shales-slates & Umbrisol \\
\hline
\end{tabular}

1987), using ethanol-free chloroform as the fumigant followed by extraction with potassium sulfate $\left(\mathrm{K}_{2} \mathrm{SO}_{4}\right)$. Extracts of fumigated and unfumigated soil were analysed for extractable organic $\mathrm{C}$ using a Shimadzu 5000A TOC analyser (Shimadzu, Milton Keynes, UK). The extracts were analysed for microbial biomass $\mathrm{N}$ by colorimetry on a continuous flow stream autoanalyser (Bran and Luebbe, Northampton, UK), following oxidation with potassium persulfate $\left(\mathrm{K}_{2} \mathrm{~S}_{2} \mathrm{O}_{8}\right)$, by mixing $1.5 \mathrm{~mL}$ filtrate with $4.5 \mathrm{~mL} 0.165 \mathrm{M} \mathrm{K}_{2} \mathrm{~S}_{2} \mathrm{O}_{8}$ then autoclaving for $30 \mathrm{~min}$ at $121^{\circ} \mathrm{C}$ (Ross, 1992). Microbial C and $\mathrm{N}$ were calculated as the difference in the respective nutrient between fumigated and unfumigated extracts, and corrected for unrecovered biomass using $k$ factors of 0.35 for microbial C (Sparling et al., 1990) and 0.54 for microbial N (Brookes et al., 1985).

Readily exchangeable phosphate (extractable P) and microbial biomass $\mathrm{P}$ were determined by hexanol fumigation and extraction with anion-exchange membranes (Kouno et al., 1995). Phosphate was recovered from anion-exchange membranes by shaking for $1 \mathrm{~h}$ in $50 \mathrm{~mL} 0.25 \mathrm{M} \mathrm{H}_{2} \mathrm{SO}_{4}$, with detection in the acid solution by automated molybdate colorimetry using a Lachat Quikchem 8500 (Hach Ltd, Loveland, CO, USA). Extractable P was determined on unfumigated samples and microbial $P$ was calculated as the difference between the fumigated and unfumigated samples, with correction for unrecovered biomass using a $k_{\mathrm{p}}$ factor of 0.4 (Jenkinson et al., 2004).

Nitrogen mineralization was derived by extraction with in situ cation and anion-exchange resins (Templer et al., 2005). We used the resin bag method to determine extractable $\mathrm{NH}_{4}$ and $\mathrm{NO}_{3}$ because standard methods of extraction of $\mathrm{NH}_{4}$ and $\mathrm{NO}_{3}$ from soils (e.g. with $\mathrm{KCl}$ ) should be performed within $24 \mathrm{~h}$ of soils sampling (Turner and Romero, 2010), which was not possible given the remote location of these sites. We were only able to determine mineralized $\mathrm{N}$ in 5 of the 14 plots, which were distributed across the gradient (210,
1000, 1500, 1750, 3025 m a.s.1.). Mixed-bed cation/anion exchange resin was placed inside nylon bags ( $4 \mathrm{~g}$ resin in each) and installed at $10 \mathrm{~cm}$ soil depth in systematically distributed locations in each 1 ha plot $(n=15)$. Resin bags were deployed for 1 month during November-December 2011 and stored at room temperature until extraction. Resin bags were shipped to the University of Aberdeen, UK, extracted using $2 \mathrm{M} \mathrm{KCl}$ (Templer et al., 2005) and concentrations of $\mathrm{NH}_{4}$ and $\mathrm{NO}_{3}$ determined colorimetrically using a Burkard SFA2 continuous-flow analyer (Burkard Scientific Ltd., Uxbridge, UK). Extractable $\mathrm{NH}_{4}$ and $\mathrm{NO}_{3}$ (total mineralized $\mathrm{N}$ ) were calculated from the difference between extracted $\mathrm{N}$ from resin deployed in the field and resin not deployed (blanks) and expressed as extractable $\mathrm{NH}_{4}-\mathrm{N}$ and $\mathrm{NO}_{3}-\mathrm{N}$ per g resin per day.

\subsection{Soil enzymes}

Three enzymes involved in $\mathrm{C}, \mathrm{N}$ and $\mathrm{P}$ cycling were measured using microplate fluorimetric assays with $200 \mu \mathrm{M}$ methylumbelliferone (MU)-linked substrates as described in Turner and Romero (2010): $\beta$-glucosidase (degradation of $\beta$-1,4-glycosidic bonds between glucose molecules), $N$-acetyl $\beta$-glucosaminidase (degradation of $N$-glycosidic bonds in chitin), and phosphomonoesterase (degradation of monoester-linked simple organic phosphates). The activities of these three enzymes have been used to indicate the stoichiometry of microbial C, N and P nutrition in global ecosystems (Sinsabaugh et al., 2008). For each soil sample, five replicate micro-plates were prepared and incubated at 2, 10, 22,30 and $40^{\circ} \mathrm{C}$ respectively for each enzyme, to allow calculation of enzyme activity at mean annual temperature for each site.

For the fluorimetric assays, $2 \mathrm{~g}$ soil (dry weight basis) was added to $200 \mathrm{~mL} 1 \mathrm{mM} \mathrm{NaN}_{3}$ solution and dispersed by stirring on a magnetic stir plate. After $5 \mathrm{~min}$ and while stirring, 
$50 \mu \mathrm{L}$ aliquots of soil suspension were removed using an 8channel pipette and dispensed into a 96-well microplate containing $50 \mu \mathrm{L}$ modified universal buffer solution (Tabatabai, 1994) adjusted to $\mathrm{pH} 4$ (approximately equivalent to soil $\mathrm{pH}$ in all sites; Table 1). Each microplate included assay wells (soil solution plus $100 \mu \mathrm{L} \mathrm{MU}$ substrate), blank wells (soil solution plus $100 \mu \mathrm{L}$ of $1 \mathrm{mM} \mathrm{NaN}_{3}$ ) and quench wells (soil solution plus $100 \mu \mathrm{L}$ MU standard). For a sub-set of samples we measured enzyme activities using substrate concentrations ranging from $10-1000 \mu \mathrm{L} \mathrm{MU}$ to check that the substrate remained in excess at the end of the incubation in our main analyses. A further control plate was prepared with the MU substrates and standards with no soil solution to determine fluorescence from substrates and quenching by soil solution in assay plates. There were eight analytical replicate wells for each assay. Microplates were incubated at each specified temperature in the range $2,10,20,30$ and $40^{\circ} \mathrm{C}$ for a time period of approximately $4,3,2,1.5$ and $1 \mathrm{~h}$, respectively. Following incubation, $50 \mu \mathrm{L}$ of $0.5 \mathrm{M} \mathrm{NaOH}$ was added to terminate the reaction, and plates were immediately analysed on a Fluostar Optima spectrofluorometer (BMG Labtech, Offenburg, Germany) with excitation at $360 \mathrm{~nm}$ and emission at $450 \mathrm{~nm}$.

\subsection{Calculations and statistics}

\subsubsection{The stoichiometry of enzyme activities and microbial biomass}

Enzyme activities were expressed on the basis of soil organic $\mathrm{C}$ (nmol MU g C ${ }^{-1} \mathrm{~min}^{-1}$ ), to allow for direct comparisons among our sites with widely different organic $\mathrm{C}$ concentrations. Enzyme activities were determined at standard temperatures $\left(2,10,20,30\right.$ and $\left.40^{\circ} \mathrm{C}\right)$ and calculated for the mean annual temperature at each site (Table 1) by fitting a linear model of activity vs. assay temperature. Hydrolytic enzyme activities, determined using MU substrates, were expressed in nmol MUg $\mathrm{C}^{-1} \mathrm{~min}^{-1}$. We determined ratios of $\mathrm{C}, \mathrm{N}$ and $\mathrm{P}$ degrading enzymes to detect relative differences in $\mathrm{N}$ and $\mathrm{P}$ limitations to microbial activity between the sites (Sinsabaugh et al., 2008). Enzyme activity ratios for $C: N, C: P$ and $N: P$ were determined, where $\mathrm{C}=\beta$-glucosidase, $\mathrm{N}=N$-acetyl $\beta$ glucosaminidase and $\mathrm{P}=$ phosphomonoesterase. Microbial $\mathrm{C}, \mathrm{N}$ and $\mathrm{P}$ and their elemental ratios were expressed as molar values $\left(\mathrm{mmol} \mathrm{kg}^{-1}\right)$, which allowed direct comparison of values with a global meta-analysis (Cleveland and Liptzin, 2007).

The indirect assessment of microbial nutrient demand according to variation in enzyme activity requires the assumption that substrate availability is the major influence on variation in enzyme activity, rather than mean annual temperature, soil moisture, soil physical structure and plant community composition. This assumption is supported by our data and elsewhere in the literature (Sinsabaugh et al., 2008; see the Supplement for further discussion).

Changes in soil properties and enzyme activities with elevation were analysed using one-way ANOVA, with "elevation" as the factor and "soil properties" or "enzyme activities" as the response variable. Further effects of elevation on soil properties, enzyme activities and enzyme ratios were examined using linear models with soil property, microbial ratio or enzyme activity/ratio as the response variable and elevation as the predictive variable.

To account for the variability along the transect in organic horizon depth and parent material, which may have confounding influences on microbial nutrient cycling, we further examined the effects of elevation on microbial and enzymatic elemental ratios among sites where organic horizon only was sampled (1500-3400 m) and among sites of constant parent material (sites on Paleozoic shales-slates; 2020-3400 m). Pair-wise comparisons were performed using Tukey posthoc analyses. Correlations among normally distributed soil properties and enzyme activities were examined using Spearman's correlations. Data were log-transformed when model residuals were non-normally distributed. Significant interactions were determined at $p \leq 0.05$. All statistical analyses were performed using R version 2.15 (R Development Core Team, 2012).

\section{Results}

\subsection{Soil carbon and nutrients}

Total soil $\mathrm{C}, \mathrm{N}$ and $\mathrm{P}$ concentrations all increased with elevation across all sites (Fig. 1, Table 2; total $\mathrm{C}$ and $\mathrm{N}$ : $p \leq 0.001$; total $\mathrm{P}: p=0.05)$. Total $\mathrm{C}$ ranged from $1.70 \%$ (at $220 \mathrm{~m}$ a.s.1.) to $46.54 \%$ (at $3030 \mathrm{~m}$ a.s.1.), total $\mathrm{N}$ ranged from $0.35 \%$ (at $194 \mathrm{~m}$ a.s.1.) to $2.49 \%$ (at $3400 \mathrm{~m}$ a.s.1.) and total $\mathrm{P}$ ranged from $0.18 \mathrm{mg} \mathrm{g}^{-1}\left(210 \mathrm{~m}\right.$ a.s.1.) to $1.44 \mathrm{mg} \mathrm{g}^{-1}$ (1750 $\mathrm{m}$ a.s.1.). The increase in $\mathrm{C}$ was relatively greater than for $\mathrm{N}$ or $\mathrm{P}$, resulting in increased $\mathrm{C}: \mathrm{N}$ (ranging from 6.7 to 19.6) and $C: P$ ratios (ranging from 49 to 521 ) with elevation (Figs. 1-2; Table 2). Similarly, the increase in total $\mathrm{N}$ was relatively greater than the increase in total $\mathrm{P}$, resulting in increased $\mathrm{N}: \mathrm{P}$ ratios with elevation (ranging from 6.7 to 28.2 ; Figs. 1-2). Ratios of $\mathrm{C}: \mathrm{N}, \mathrm{C}: \mathrm{P}$ and $\mathrm{N}: \mathrm{P}$ increased significantly with elevation $(p<0.001, p<0.01, p<0.05$, respectively), although with higher variation for $\mathrm{C}: \mathrm{P}$ and $\mathrm{N}: \mathrm{P}$ than $\mathrm{C}: \mathrm{N}$ (Fig. 2). Total soil $\mathrm{C}$ and $\mathrm{N}$ across all sites were closely correlated $\left(R^{2}=0.93, p<0.001\right)$, in contrast to marginal relationships between total $\mathrm{C}$ and $\mathrm{P}\left(R^{2}=0.07, p<0.05\right)$ and total $\mathrm{N}$ and $\mathrm{P}\left(R^{2}=0.10, p=0.01\right.$; Fig. 1$)$. Soil $\mathrm{pH}$ ranged from 3.8 to 4.6 among sites, but did not vary significantly with elevation (Table 2).

There were major contrasts in the concentrations of total mineralized $\mathrm{N}$ and extractable $\mathrm{PO}_{4}$ with elevation (Table 2, Fig. 3). Mineralized $\mathrm{NO}_{3}$ decreased with elevation 
Table 2. Soil nutrients and $\mathrm{pH}$ along the elevation gradient. Linear model results (elevation $\sim$ property) are given at the bottom of the table. Values are means $\pm 1 \mathrm{SE}(n=5)$.

\begin{tabular}{|c|c|c|c|c|c|c|c|c|c|c|c|}
\hline $\begin{array}{l}\text { Site } \\
\text { code }\end{array}$ & $\begin{array}{r}\text { Elevation } \\
\text { (ma.s.1.) }\end{array}$ & $\begin{array}{r}\text { Total C } \\
(\%)\end{array}$ & $\begin{array}{r}\text { Total N } \\
(\%)\end{array}$ & $\begin{array}{r}\text { Total P } \\
\left(\mathrm{mg} \mathrm{P} \mathrm{g}^{-1}\right)\end{array}$ & Total C: N & Total C: P & Total N:P & $\begin{array}{r}\operatorname{Resin} \mathrm{NO}_{3} \\
\left(\mu \mathrm{gNg}^{-1} \mathrm{~d}^{-1}\right)\end{array}$ & $\begin{array}{r}\text { Resin } \mathrm{NH}_{4} \\
\left(\mu \mathrm{gNg}^{-1} \mathrm{~d}^{-1}\right)\end{array}$ & $\begin{array}{r}\text { Extractable } \mathrm{PO}_{4} \\
\left(\mathrm{mg} \mathrm{Pkg}^{-1}\right)\end{array}$ & Soil pH \\
\hline TAM-06 & 194 & $2.38(0.32)$ & $0.35(0.03)$ & $0.49(0.07)$ & 6.7 & 48.6 & 7.1 & - & - & $3.3(0.8)$ & $4.6(0.1)$ \\
\hline TAM-05 & 210 & $1.70(0.25)$ & $0.23(0.03)$ & $0.18(0.03)$ & 7.1 & 94.4 & 12.8 & $24.21(2.94)$ & $3.38(0.45)$ & $2.7(0.2)$ & $3.8(0.1)$ \\
\hline $\mathrm{VC}$ & 1000 & $16.2(1.6)$ & $1.34(0.12)$ & $0.73(0.05)$ & 11.5 & 222.3 & 18.4 & $14.25(1.94)$ & $9.64(1.23)$ & $0.7(0.1)$ & $3.8(0.1)$ \\
\hline SPD-2 & 1500 & $10.3(1.8)$ & $0.91(0.12)$ & $1.36(0.37)$ & 11.2 & 76.0 & 6.7 & $14.11(3.22)$ & $13.06(0.68)$ & $44.7(20.1)$ & $4.0(0.1)$ \\
\hline SPD-1 & 1750 & $26.0(10.0)$ & $1.56(0.50)$ & $1.44(0.09)$ & 14.7 & 180.3 & 10.8 & $0.33(0.08)$ & $13.91(1.02)$ & $19.0(3.0)$ & $3.9(0.1)$ \\
\hline TRU-08 & 1850 & $31.1(4.6)$ & $1.86(0.21)$ & $0.76(0.06)$ & 16.5 & 409.2 & 24.5 & - & - & 14.4 (3.7) & $3.9(0.1)$ \\
\hline TRU-07 & 2020 & $37.0(4.8)$ & $2.00(0.24)$ & $0.71(0.10)$ & 18.6 & 520.6 & 28.2 & - & - & $16.3(4.7)$ & $4.0(0.1)$ \\
\hline TRU-05 & 2520 & $25.8(5.7)$ & $1.73(0.34)$ & $0.98(0.14)$ & 14.7 & 263.6 & 17.7 & - & - & $53.1(8.6)$ & $3.9(0.1)$ \\
\hline TRU-04 & 2720 & $28.6(5.0)$ & $1.64(0.25)$ & $0.87(0.19)$ & 17.0 & 329.0 & 18.9 & - & - & $56.0(12.8)$ & $3.9(0.1)$ \\
\hline TRU-03 & 3020 & $27.1(5.5)$ & $1.57(0.21)$ & $0.92(0.13)$ & 16.6 & 294.6 & 17.1 & - & - & $59.7(20.7)$ & $3.8(0.1)$ \\
\hline WAY-01 & 3025 & $46.5(2.1)$ & $2.39(0.12)$ & $1.09(0.08)$ & 19.6 & 427.0 & 21.9 & $0.47(0.21)$ & $11.87(0.88)$ & $82.0(23.3)$ & $4.1(0.1)$ \\
\hline TRU-02 & 3200 & $44.8(1.8)$ & $2.42(0.20)$ & $0.91(0.02)$ & 18.9 & 492.6 & 26.6 & - & - & $72.8(12.9)$ & $4.1(0.7)$ \\
\hline \multirow[t]{4}{*}{ TRU-01 } & 3400 & $42.1(3.1)$ & $2.49(0.17)$ & $1.09(0.09)$ & 17.0 & 386.1 & 22.9 & - & - & $223.5(33.0)$ & $4.0(0.2)$ \\
\hline & $R^{2}$ & 0.79 & 0.80 & 0.30 & 0.80 & 0.55 & 0.38 & 0.73 & 0.12 & 0.51 & 0.13 \\
\hline & $F$ & 40.76 & 42.98 & 4.61 & 45.21 & 13.27 & 6.75 & 154.92 & 8.06 & 11.3 & 1.66 \\
\hline & $P$ & $<0.001$ & $<0.001$ & 0.05 & $<0.001$ & $<0.01$ & 0.03 & $<0.001$ & $<0.01$ & $<0.01$ & 0.22 \\
\hline
\end{tabular}
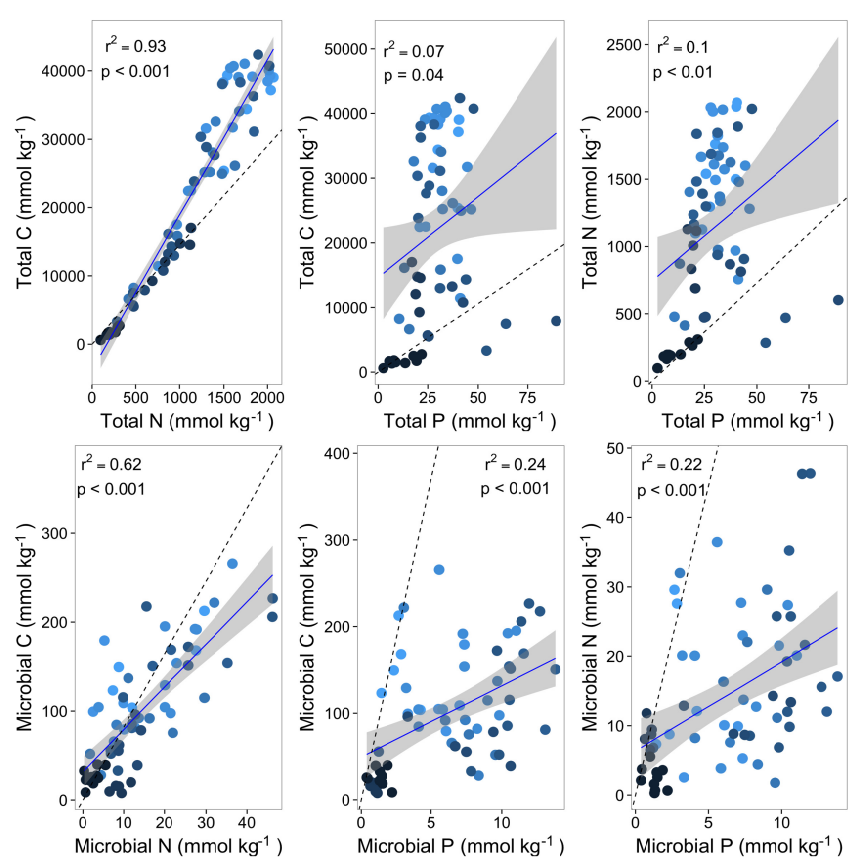

Figure 1. The stoichiometry of total soil $\mathrm{C}, \mathrm{N}$ and $\mathrm{P}$, and soil microbial $\mathrm{C}, \mathrm{N}$ and $\mathrm{P}$ (molar ratios). The points are coloured according to the elevation gradient (194-3400 m a.s.1.), with darker points for lower elevation sites and lighter points for higher elevation sites. The solid lines are linear regressions between total and microbial elements (model parameters are reported in the top-right of each panel). The shaded areas represent \pm 1 SE. The dashed lines represent the stoichiometric scaling of $\mathrm{C}: \mathrm{N}: \mathrm{P}$ from a recent global meta-analysis of forests $(212: 15: 1$ in soils and $74: 9: 1$ in microbial biomass; Cleveland and Liptzin, 2007).

( $p<0.001)$ from $24.21 \mu \mathrm{g} \mathrm{Ng} \operatorname{resin}^{-1} \mathrm{~d}^{-1}$ (210 ma.s.1.) to $0.33 \mu \mathrm{g} \mathrm{Ng} \operatorname{resin}^{-1} \mathrm{~d}^{-1}$ (1750 ma.s.l.), whereas mineralized $\mathrm{NH}_{4}$ increased with elevation $(p<0.01)$. However, total mineralized $\mathrm{N}\left(\mathrm{NO}_{3}+\mathrm{NH}_{4}\right)$ decreased with elevation
$\left(R^{2}=0.61, p<0.001\right.$; Fig. 3$)$. In contrast, extractable $\mathrm{PO}_{4}$ increased with elevation $(p<0.001)$ from $0.7 \mathrm{mg} \mathrm{P} \mathrm{kg}^{-1}$ (at $1000 \mathrm{~m}$ a.s.l.) to $223.5 \mathrm{mg} \mathrm{P} \mathrm{kg}^{-1}$ (at $3400 \mathrm{~m}$ a.s.l.; Table 2; Fig. 3).

\subsection{Soil microbial nutrients and $\mathrm{C}: \mathrm{N}: \mathrm{P}$ ratios}

Soil microbial $\mathrm{C}, \mathrm{N}$ and $\mathrm{P}$ all increased with elevation and ranged 10-fold among sites (Table 3), which approximately corresponded with the increase in organic matter and soil $C$ with elevation (Table 2). The increase was linear and highly significant for microbial C $\left(R^{2}=0.61, p<0.01\right)$ and microbial N $\left(R^{2}=0.35, p<0.05\right)$, but not for microbial $\mathrm{P}$ $\left(R^{2}=0.16, p=0.18\right)$, which peaked in mid-elevation sites (1850 and $2020 \mathrm{~m}$ a.s.1.). Microbial $\mathrm{C}$ and $\mathrm{N}$ were closely correlated among all sites $\left(R^{2}=0.62, p<0.001\right)$, in contrast to the less well-constrained relationships between microbial $\mathrm{C}$ and microbial $\mathrm{P}\left(R^{2}=0.24, p<0.001\right)$, and microbial $\mathrm{N}$ and microbial $\mathrm{P}\left(R^{2}=0.22, p<0.001\right)$ (Fig. 1).

Despite the large differences in microbial nutrients, ratios of microbial $\mathrm{C}: \mathrm{N}, \mathrm{C}: \mathrm{P}$ and $\mathrm{N}: \mathrm{P}$ did not vary with elevation across the entire transect $\left(R^{2}=0.04, p=0.51 ; R^{2}=0.07\right.$, $p=0.39 ; R^{2}<0.01, p=0.77$; Table 3; Fig. 2). However, among sites where only organic horizons were sampled, there was a slight increase in microbial $\mathrm{C}: \mathrm{N}$ and $\mathrm{N}: \mathrm{P}$ ratios with elevation, and a greater increase for microbial $\mathrm{C}: \mathrm{P}$ (Table 4). Similarly, among sites on the same parent material there was an elevation-related increase in microbial $\mathrm{C}: \mathrm{P}$ (Table 4).

\subsection{Enzyme activities}

All enzyme activities decreased significantly with elevation, when determined at standard assay temperature $(p<0.001$ for all comparisons; see Fig. S1 in the Supplement for activity determined at assay temperatures 10 and $30^{\circ} \mathrm{C}$ ) and when determined at the mean annual temperature for each 

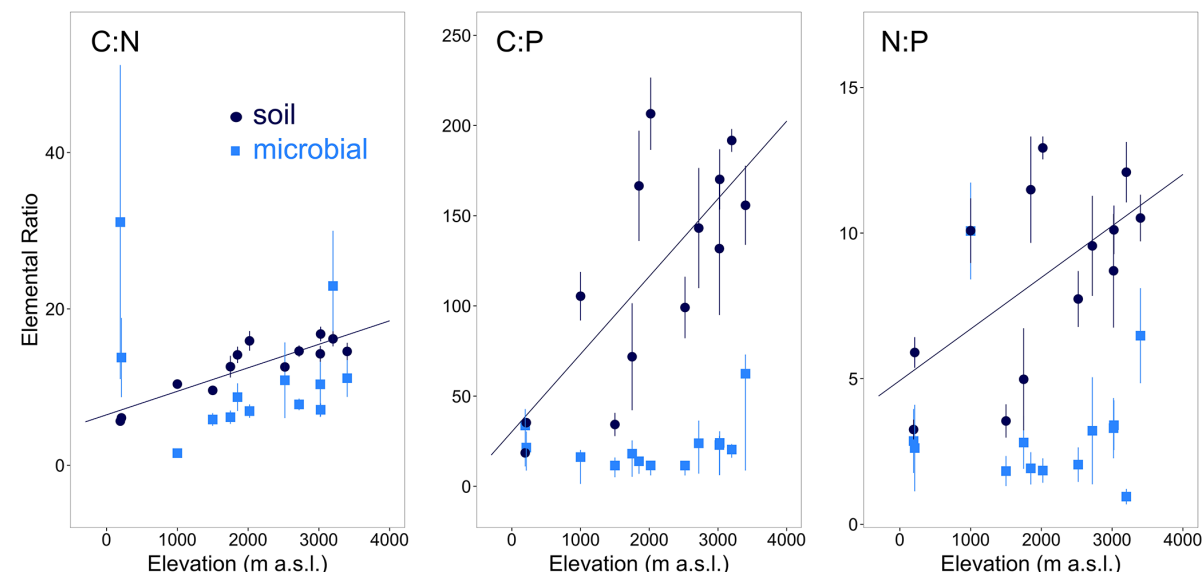

Figure 2. The relationships between soil and microbial $\mathrm{C}: \mathrm{N}: \mathrm{P}$ stoichiometry with elevation (194-3400 $\mathrm{m}$ a.s.1.). Total soil $\mathrm{C}: \mathrm{N}, \mathrm{C}: \mathrm{P}$ and $\mathrm{N}: \mathrm{P}$ all significantly varied with elevation $\left(R^{2}=0.45,0.36,0.28\right.$, respectively $p<0.05$; see Table 2$)$. Microbial $\mathrm{C}: \mathrm{P}, \mathrm{C}: \mathrm{N}$ and $\mathrm{N}: \mathrm{P}$ ratios did not vary with elevation. Values are means $\pm 1 \mathrm{SE}(n=5$ replicates, which represents the spatial variation within a 1 ha plot).

Table 3. Carbon $(\mathrm{C})$, nitrogen $(\mathrm{N})$ and phosphorus $(\mathrm{P})$ and their ratios in soil microbial biomass along the elevation gradient. Linear model results (elevation $\sim$ property) are given at the bottom of the table. Values are means $\pm 1 \mathrm{SE}(n=5)$.

\begin{tabular}{lrrrrrrr}
\hline $\begin{array}{l}\text { Site } \\
\text { code }\end{array}$ & $\begin{array}{r}\text { Elevation } \\
(\mathrm{m} \text { a.s.1.) }\end{array}$ & $\begin{array}{r}\text { Microbial C } \\
\left(\mathrm{mmol} \mathrm{kg}^{-1}\right)\end{array}$ & $\begin{array}{r}\text { Microbial N } \\
\left(\mathrm{mmol} \mathrm{kg}^{-1}\right)\end{array}$ & $\begin{array}{r}\text { Microbial P } \\
\left(\mathrm{mmol} \mathrm{kg}^{-1}\right)\end{array}$ & Microbial C:N & Microbial C:P & Microbial N:P \\
\hline TAM-06 & 194 & $32.1(3.5)$ & $2.6(0.9)$ & $1.18(0.24)$ & $31.1(20.1)$ & $33.7(9.1)$ & $2.9(1.1)$ \\
TAM-05 & 210 & $20.5(3.3)$ & $2.2(0.7)$ & $1.40(0.28)$ & $13.8(5.1)$ & $21.5(8.9)$ & $2.6(1.5)$ \\
VC & 1000 & $13.8(2.2)$ & $8.9(0.9)$ & $0.94(0.10)$ & $1.6(0.2)$ & $16.2(3.9)$ & $10.1(1.7)$ \\
SPD-2 & 1500 & $66.2(9.8)$ & $11.6(1.2)$ & $7.50(1.26)$ & $5.9(0.8)$ & $11.5(4.4)$ & $1.8(0.5)$ \\
SPD-1 & 1750 & $103.7(35.4)$ & $18.9(7.7)$ & $7.98(1.78)$ & $6.1(0.9)$ & $18.1(7.4)$ & $2.8(0.9)$ \\
TRU-08 & 1850 & $159.3(27.7)$ & $21.9(6.7)$ & $11.26(0.47)$ & $8.7(1.8)$ & $13.9(2.0)$ & $1.9(0.6)$ \\
TRU-07 & 2020 & $138.6(17.5)$ & $21.1(3.9)$ & $11.89(0.69)$ & $6.9(0.9)$ & $11.6(1.8)$ & $1.8(0.4)$ \\
TRU-05 & 2520 & $94.2(14.9)$ & $16.2(4.7)$ & $8.37(0.70)$ & $10.9(4.8)$ & $11.5(1.8)$ & $2.0(0.6)$ \\
TRU-04 & 2720 & $98.5(32.8)$ & $13.2(4.9)$ & $5.87(1.00)$ & $7.8(0.7)$ & $23.9(12.5)$ & $3.2(1.8)$ \\
TRU-03 & 3020 & $114.8(12.3)$ & $16.0(3.5)$ & $5.74(0.95)$ & $10.4(4.2)$ & $22.9(5.0)$ & $3.3(1.0)$ \\
WAY-01 & 3025 & $188.4(26.7)$ & $26.6(2.9)$ & $8.81(1.04)$ & $7.1(0.8)$ & $24.0(6.5)$ & $3.4(0.9)$ \\
TRU-02 & 3200 & $114.3(17.0)$ & $7.0(1.7)$ & $5.85(0.71)$ & $22.9(7.1)$ & $20.4(3.0)$ & $0.9(0.3)$ \\
TRU-01 & 3400 & $151.5(18.8)$ & $17.1(4.8)$ & $2.71(0.45)$ & $11.1(2.4)$ & $62.4(10.7)$ & $6.5(1.6)$ \\
\hline & $R^{2}$ & 0.61 & 0.35 & 0.16 & 0.04 & 0.07 & $<0.01$ \\
& $F$ & 16.95 & 5.88 & 2.06 & 0.46 & 0.80 & 0.09 \\
& $p$ & $<0.01$ & $<0.05$ & 0.18 & 0.51 & 0.39 & 0.77 \\
\hline
\end{tabular}

site (Fig. 4). To determine enzyme activity at the mean annual temperature, we used linear models of enzyme activity against assay temperature; all of the 42 models (for 3 enzymes and 13 sites) were significant $(p<0.05)$ and the average $R^{2}$ of all fitted models was 0.80 ( $\mathrm{SE}=0.01, n=39$; Table $\mathrm{S} 1$ in the Supplement). After accounting for differences in soil $\mathrm{C}$ content among sites, enzyme activities decreased approximately 100-fold with elevation (Fig. 4). The largest decline in enzyme activity with elevation was for phosphomonoesterase and the smallest decline was for $N$-acetyl $\beta$ glucosaminidase (Fig. 4; note log scale for enzyme activity).

The enzymatic $\mathrm{C}: \mathrm{P}$ and $\mathrm{N}: \mathrm{P}$ ratios increased with elevation (Fig. 5), but not for $\mathrm{C}: \mathrm{N}$. The relatively large de- crease in phosphomonoesterase activity with elevation compared to other enzymes was reflected by increasing ratios for enzymatic $\mathrm{C}: \mathrm{P}\left(R^{2}=0.18, p<0.001\right)$ and $\mathrm{N}: \mathrm{P}\left(R^{2}=0.13\right.$, $p<0.01)$ but not for $\mathrm{C}: \mathrm{N}\left(R^{2}=0.04, p=0.13\right.$; Fig. 5). Among sites where only the organic horizon was sampled, the pattern of an elevation related increase for enzymatic $\mathrm{C}: \mathrm{P}$ and $\mathrm{N}: \mathrm{P}$, but not $\mathrm{C}: \mathrm{N}$, was also observed (Table 4). Among sites of constant parent material, there was an elevation-related increase for enzymatic $\mathrm{N}: \mathrm{P}$ and a marginal increase for enzymatic $\mathrm{C}: \mathrm{P}$ (Table 4). 
Table 4. Relationships between elevation and microbial and enzymatic carbon $(\mathrm{C})$, nitrogen $(\mathrm{N})$ and phosphorus $(\mathrm{P})$ ratios, in organic soils only (sites 1500-3400 m a.s.l.) and in soils of constant parent material (sites 2020-3400 m a.s.1.). The relationships between elevation and microbial and enzymatic carbon, nitrogen and phosphorus ratios for all sites across the gradient are shown in Figs. 3 and 5, respectively. Significant relationships are in bold $(p \leq 0.05)$.

\begin{tabular}{|c|c|c|c|c|c|c|}
\hline & Microbial C : N & Microbial C:P & Microbial N : P & Enzymatic $\mathrm{C}: \mathrm{N}$ & Enzymatic $\mathrm{C}: \mathrm{P}$ & Enzymatic $\mathrm{N}: \mathrm{P}$ \\
\hline $1500-3400 \mathrm{~m}$ & \multicolumn{6}{|c|}{ Constant organic horizon } \\
\hline Slope & 28 & 576 & 78 & -142 & 730 & 990 \\
\hline$R^{2}$ & 0.09 & 0.22 & 0.07 & -0.02 & 0.09 & 0.15 \\
\hline$F$ & 5.70 & 14.33 & 4.63 & 0.13 & 5.82 & 9.52 \\
\hline$P$ & 0.02 & $<0.001$ & 0.04 & 0.72 & 0.02 & $<0.01$ \\
\hline $2020-3400 \mathrm{~m}$ & \multicolumn{6}{|c|}{ Constant parent material } \\
\hline Slope & 12 & 10 & 49 & -212 & 427 & 757 \\
\hline$R^{2}$ & 0.06 & 0.28 & 0.10 & 0.02 & 0.11 & 0.25 \\
\hline$F$ & 1.97 & 12.30 & 3.51 & 0.56 & 3.97 & 11.02 \\
\hline$p$ & 0.17 & 0.001 & 0.07 & 0.46 & 0.055 & $<0.01$ \\
\hline
\end{tabular}

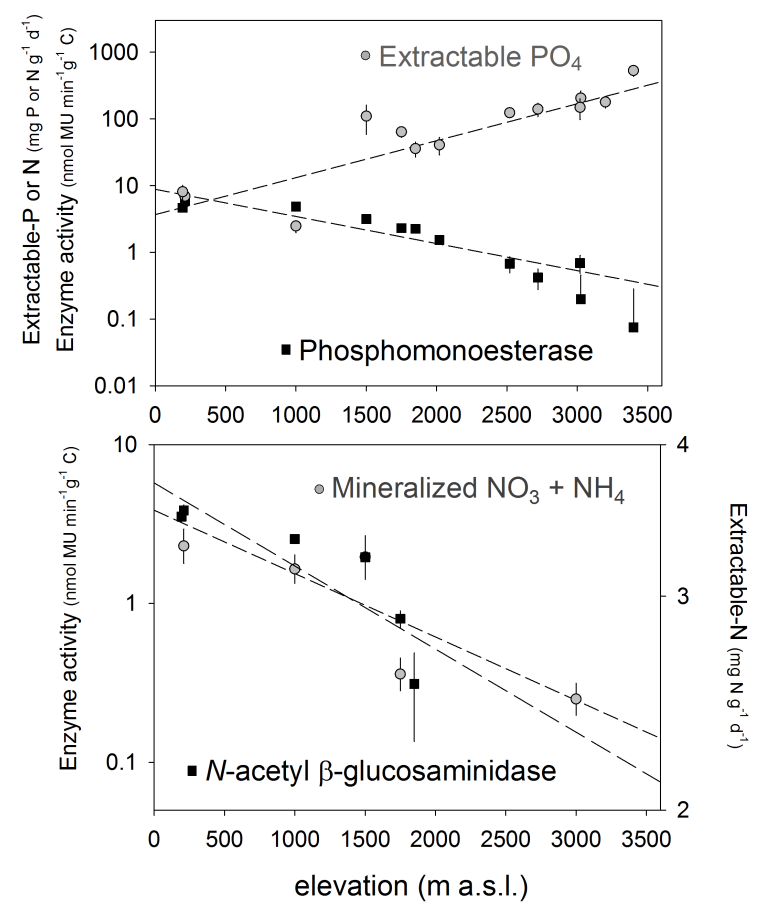

Figure 3. The decline in phosphomonoesterase activity and increase in resin-extractable $\mathrm{P}$ with elevation; and the decline in $N$-acetyl $\beta$ glucosaminidase activity and decline in total mineralized $\mathrm{N}\left(\mathrm{NO}_{3}+\right.$ $\mathrm{NH}_{4}$ ) with elevation. Linear regressions are shown, where $p<0.05$. Spearman correlation coefficients are reported in Table 4. Values are means $\pm 1 \mathrm{SE}(n=5)$.

\section{Discussion}

It has been proposed that tropical forest elevation gradients are gradients of nutrient limitation on plant productivity, with $\mathrm{P}$ limitation prevalent in lowland forests (Vitousek and Sanford, 1986) and $\mathrm{N}$ limitation prevalent in montane forests

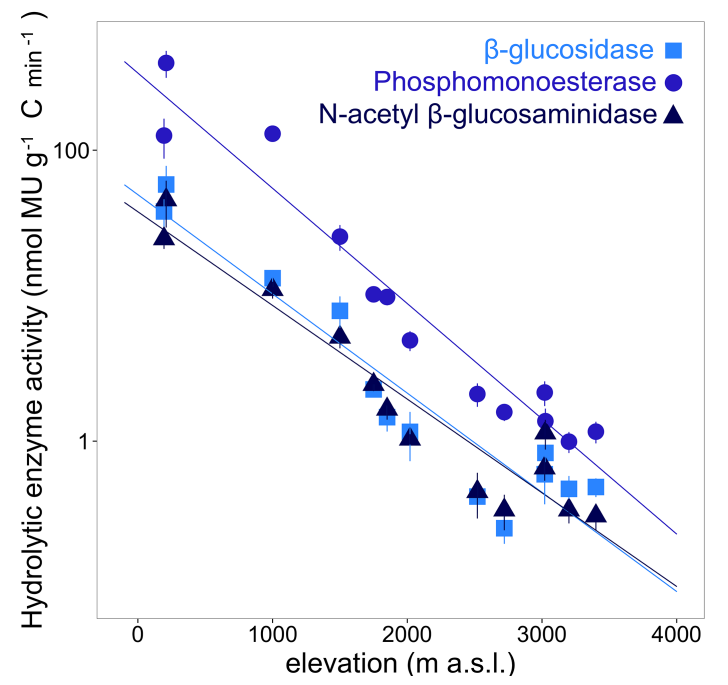

Figure 4. Enzyme activities of $\mathrm{C}$ ( $\beta$-glucosidase) $\mathrm{N}$ ( $N$-acetyl $\beta$ glucosaminidase) and $\mathrm{P}$ (phosphomonoesterase) - degrading enzymes for 13 sites at elevations ranging from 194 to $3400 \mathrm{~m}$, determined at the mean annual temperature (MAT) for each site (Table 1). Enzyme activity at MAT was determined using linear regression of temperature and enzyme activities determined at 2, 10, 22 and $30{ }^{\circ} \mathrm{C}$ (Table $\mathrm{S} 1$ ). Linear regressions are shown, where $p<0.05$. Values are means $\pm 1 \mathrm{SE}$ ( $n=5$ replicates, which represents the spatial variation within a 1 ha plot).

(Tanner et al., 1998). The major drivers of this shift are considered to be differences in soil nutrient availability along elevation gradients, caused by changes in rates of soil weathering and turnover, and temperature constraints on decomposition and biological N fixation (Hedin et al., 2009; Reed et al., 2011; Tanner et al., 1998). Therefore, it is reasonable to hypothesize that soil microbial processes are constrained by $\mathrm{N}$ and $\mathrm{P}$ in the same manner, which is supported for some low- 

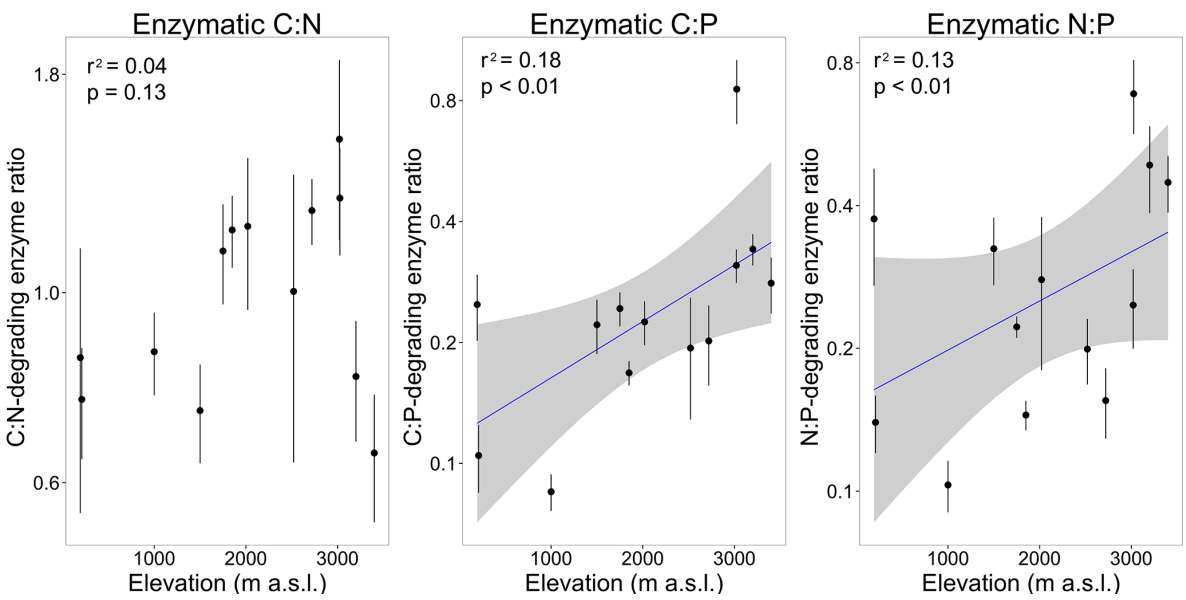

Figure 5. The stoichiometry of $\mathrm{C}$ ( $\beta$-glucosidase), $\mathrm{N}$ ( $N$-acetyl $\beta$-glucosaminidase) and $\mathrm{P}$ (phosphomonoesterase) - degrading enzyme activity along a tropical forest $3400 \mathrm{~m}$ elevation gradient. Enzymes activities were determined at the mean annual temperature for each site. Linear models (including all 13 sites) explained the variation in enzymatic ratios with elevation for $\mathrm{C}: \mathrm{P}_{\mathrm{en}}\left(R^{2}=0.18, p<0.001\right)$ and $\mathrm{N}: \mathrm{P}_{\mathrm{en}}$ $\left(R^{2}=0.13, p<0.01\right)$, but not $\mathrm{C}: \mathrm{N}_{\mathrm{en}}\left(R^{2}=0.04, p=0.13\right)$. Values are means $\pm 1 \mathrm{SE}(n=5)$.

land (Cleveland et al., 2002; Turner and Wright, 2014) and montane tropical forests sites (Corre et al., 2010; Cusack et al., 2011a). Our findings from a $3400 \mathrm{~m}$ tropical forest elevation gradient in the Peruvian Andes provide evidence that this paradigm also applies to soil microorganisms, with a gradual transition in investment in nutrient acquisition from $\mathrm{P}$ to $\mathrm{N}$ between lowland and montane tropical forests.

Evidence that relative microbial investment in nutrient acquisition shifts from $\mathrm{P}$ towards $\mathrm{N}$ along a tropical elevation gradient can be inferred from differences in nutrient availability and enzyme activity. An increasing P constraint on microbial metabolism with decreasing elevation is supported by the significantly lower concentrations of total and extractable $\mathrm{P}$ in low elevation soils (Table 2). Phosphomonoesterase activity was strongly correlated with extractable P (Fig. 3), suggesting that increased microbial synthesis of phosphatases at lower elevations was a direct response to low available phosphate. This apparent strong $\mathrm{P}$ constraint on microbial processes in low elevation forests is consistent with increased rates of litter decomposition (Kaspari et al., 2008), C mineralization (Cleveland and Townsend, 2006), greater microbial biomass and decreased phosphomonoesterase activity (Turner and Wright, 2014), following P addition to lowland tropical forests.

Evidence of increasing $\mathrm{N}$ constraints on microbial metabolism with increasing elevation included a strong reduction in total mineralized $\mathrm{N}$ (the sum of resin $\mathrm{NO}_{3}+\mathrm{NH}_{4}$; Table 2, Fig. 3) and increase in the enzymatic N:P ratio at higher elevations, coupled with an overall decline in the activity of all enzymes, presumably because of the high $\mathrm{N}$ requirement for building proteins (Allison et al., 2010; Loladze and Elser, 2011; Fig. 4). Given that microbial N requirements are largely determined by the rates of protein synthesis (Loladze and Elser, 2011), there must be a threshold at which $\mathrm{N}$ scarcity begins to limit the synthesis of $N$-acetyl $\beta$-glucosaminidase and other $\mathrm{N}$-acquiring enzymes (Olander and Vitousek, 2000). Other studies of tropical montane forests, including these sites in Peru, provide evidence that low $\mathrm{N}$ availability constrains microbial processes at higher elevation. For example, $\mathrm{N}$ limitation of microbial metabolism was indicated by increased heterotrophic soil $\mathrm{CO}_{2}$ efflux following $\mathrm{N}$ fertilization at the $3030 \mathrm{~m}$ elevation site studied here (Fisher et al., 2013). In other montane tropical forests, $\mathrm{N}$ fertilization stimulated microbial biomass (Corre et al., 2010; Cusack et al., 2011b) and increased the activity of hydrolytic enzymes (Cusack et al., 2011b), which supports our finding of $\mathrm{N}$ limitation of microbial synthesis of hydrolytic enzymes in tropical montane forests (Figs. 3, 5).

In contrast, microbial nutrient ratios did not vary over the entire gradient (Fig. 2), which does not support the hypothesis of a shift in nutrient constraints on microbial biomass from $\mathrm{P}$ towards $\mathrm{N}$ with increased elevation. There were slight elevation-related increases in microbial $\mathrm{C}: \mathrm{N}$ and $\mathrm{C}: \mathrm{P}$ ratios in organic soils (Table 4), which can be explained by increased dominance of the microbial biomass at higher elevation by fungi (Whitaker et al., 2014), which have wider C:nutrient ratios compared to bacteria (Six et al., 2006). The overall pattern of relatively constant elemental ratios in the microbial biomass despite large differences in nutrient availability (Fig. 2) can be explained by microbial stoichiometric homeostasis. Although non-homeostatic patterns have been found in marine, freshwater and terrestrial autotrophs (Elser et al., 2009, 2007; Redfield, 1958), homeostasis of microbial nutrition has been demonstrated in cultured bacteria (Makino et al., 2003) and is supported in field studies and observations of constrained soil microbial elemental ratios across ecosystems worldwide (Cleveland and Liptzin, 2007; Hartman and Richardson, 2013). For example, despite an order- 
of-magnitude shift in soil $\mathrm{P}$ relative to soil $\mathrm{N}$ concentrations across the 120000 year Franz Josef temperate rainforest chronosequence, microbial $\mathrm{N}: \mathrm{P}$ ratios remained relatively constant throughout the majority of the sequence $(5.9 \pm 0.7$, compared to $3.3 \pm 0.7$ in this study; Turner et al., 2013), while a decade of nutrient addition had no effect on microbial N : $\mathrm{P}$ ratios in lowland tropical forest in Panama (Turner and Wright, 2014). The list of possible mechanisms by which heterotrophs maintain homeostasis includes their capacity to alter soil nutrient availability by synthesising extracellular enzymes (Sinsabaugh et al., 2009) and to immobilize large amounts of $\mathrm{N}$ and $\mathrm{P}$, resulting in low $\mathrm{C}: \mathrm{N}$ and $\mathrm{C}: \mathrm{P}$ ratios compared to total soil nutrients and leaf litter (Cleveland and Liptzin, 2007; McGroddy et al., 2004; Sterner and Elser, 2002; Turner and Wright, 2014). For example, it appears that relatively high microbial $\mathrm{P}$ immobilization occurred in these tropical soils because microbial $\mathrm{C}: \mathrm{P}$ ratios were low when compared to a global data set (Fig. 1; Cleveland and Liptzin, 2007).

The major drivers of this shift in microbial investment in nutrient acquisition from $\mathrm{P}$ towards $\mathrm{N}$ appear to be differences in soil weathering, bedrock turnover and temperature. Evidence for the role of pedogenic processes comes from the consistent pattern of increased enzymatic $\mathrm{N}: \mathrm{P}$ ratios in sites on the same parent material (Table 4) and the greatest $P$ constraints on the microbial biomass in the strongly weathered lowland forest soils, which were depleted of primary minerals (e.g. Haplic Alisols relative to Umbrisols; Quesada et al., 2010; Reed et al., 2011; Vitousek, 1984; Table 2). The significant tectonic uplift in the upper Andes (Garzione et al., 2008), together with significant landslide activity and erosion rates reported for this gradient (Clark et al., 2013) likely decrease $\mathrm{P}$ constraints in soils on steeper slopes at high elevation by replenishing $P$ and other rock-derived minerals (Porder and Hilley, 2010). Evidence for the role of low temperature in promoting $\mathrm{N}$ constraints at higher elevation comes from studies suggesting a reduction in biological $\mathrm{N}$ fixation and $\mathrm{N}$ mineralization in montane forests (Bruijnzeel et al., 2011; Table 2). Low rates of $\mathrm{N}$ mineralization have been reported in montane tropical forests in Costa Rica (Marrs et al., 1988), Panama (Corre et al., 2010), Hawaii (Hall and Matson, 2003) and Ecuador (Arnold et al., 2009; Wolf et al., 2011).

As with any natural environmental gradient, there are a number of other co-varying factors that may influence our conclusions, including differences in parent material, soil development, rainfall patterns and plant community composition (Körner, 2007). In our study we constrained the covarying influences of organic soil depth and parent material in separate analyses, showing that they did not influence our main finding of a shift from $\mathrm{P}$ to $\mathrm{N}$ constraints on microbial acquisition with elevation (Table 4). Mean annual rainfall is high at all sites but peaks at mid-elevation (Table 1 ), suggesting greater soil weathering rates and leaching of available soil P for these sites. However, the high P concen- tration in these soils (Table 2) suggests that losses through weathering are minor relative to inputs of rock-derived $\mathrm{P}$ through high erosion rates and landslide activity (Clark et al., 2013). The interactions between plant communities and soils along this gradient more likely re-enforce the shift in nutrient constraints through feedbacks between plant productivity, leaf litter quality and decomposition rates. For example, lower productivity of montane forest plants (Girardin et al., 2010) with lower leaf N : P ratios (van de Weg et al., 2009, 2014) may further slow decomposition rates and the supply of bioavailable soil $\mathrm{N}$ (Wardle et al., 2004).

Our understanding of how nutrients may regulate the $\mathrm{C}$ cycle in lowland and montane tropical forest is largely based on the responses of aboveground production, whereas the responses of belowground processes remain relatively unknown. Along a $3400 \mathrm{~m}$ elevation transect in the Peruvian Andes we provide evidence to support the hypothesis that soil microbial activity, and by inference heterotrophic decomposition and respiration of organic matter, is predominantly constrained by $\mathrm{P}$ in lowland forests but by $\mathrm{N}$ in montane forests. Despite these constraints, our results suggest that the microbial biomass is relatively homeostatic with respect to nutrients, given the major changes in $\mathrm{N}$ and $\mathrm{P}$ availability along the elevation gradient. Extrapolating our findings to other sites requires careful consideration of the multiple factors that influence nutrient availability and co-vary with elevation, including differences in parent material and rainfall. Nevertheless these results have important implications for $\mathrm{C}$ cycling in tropical ecosystems because nutrient constraints are important factors in determining how these ecosystems respond to perturbations in climate, atmospheric $\mathrm{CO}_{2}$ and nutrient enrichment.

\section{The Supplement related to this article is available online at doi:10.5194/bg-12-6071-2015-supplement.}

Acknowledgements. This study is a product of the Andes Biodiversity and Ecosystem Research Group consortium (www.andesconservation.org) and was financed by the UK Natural Environment Research Council (NERC), grant nos. NE/G018278/1 and NE/F002149/1 and also supported by Australian Research Council grant FT110100457 to P. Meir and a European Union Marie Curie Fellowship FP7-2012-329360 to A. T. Nottingham. We thank the Asociacion para la Conservacion de la Cuenca Amazonica (ACCA) in Cusco and the Instituto Nacional de Recursos Naturales (INRENA) in Lima for access to the study sites. For their logistical support we thank Eric Cosio and Eliana Esparza Ballón at Pontificia Universidad Católica del Perú (PUCP). For their support in the laboratory we thank Tania Romero and Dayana Agudo. For their support in the field we thank Adan J. Q. Ccahuana, Walter H. Huasco and Javier E. S. Espejo.

Edited by: S. Zaehle 


\section{References}

Allison, S. D. and Vitousek, P. M.: Responses of extracellular enzymes to simple and complex nutrient inputs, Soil Biol. Biochem., 37, 937-944, 2005.

Allison, S. D., Weintraub, M. N., Gartner, T. B., and Waldrop, M. P.: Evolutionary-economic principles as regulators of soil enzyme production and ecosystem function, In: Soil Enzymology, edited by: Shulka, G. and Varma, A., Springer-Verlag, Berlin, 229-243, 2010.

Allison, V. J., Condron, L. M., Peltzer, D. A., Richardson, S. J., and Turner, B. L.: Changes in enzyme activities and soil microbial community composition along carbon and nutrient gradients at the Franz Josef chronosequence, New Zealand, Soil Biol. Biochem., 39, 1770-1781, 2007.

Alvarez-Clare, S., Mack, M. C., and Brooks, M.: A direct test of nitrogen and phosphorus limitation to net primary productivity in a lowland tropical wet forest, Ecology, 94, 1540-1551, 2013.

Aragão, L. E. O. C., Malhi, Y., Metcalfe, D. B., Silva-Espejo, J. E., Jiménez, E., Navarrete, D., Almeida, S., Costa, A. C. L., Salinas, N., Phillips, O. L., Anderson, L. O., Alvarez, E., Baker, T. R., Goncalvez, P. H., Huamán-Ovalle, J., Mamani-Solórzano, M., Meir, P., Monteagudo, A., Patiño, S., Peñuela, M. C., Prieto, A., Quesada, C. A., Rozas-Dávila, A., Rudas, A., Silva Jr., J. A., and Vásquez, R.: Above- and below-ground net primary productivity across ten Amazonian forests on contrasting soils, Biogeosciences, 6, 2759-2778, doi:10.5194/bg-6-2759-2009, 2009.

Arnold, J., Corre, M. D., and Veldkamp, E.: Soil N cycling in oldgrowth forests across an Andosol toposequence in Ecuador, Forest Ecol. Manag., 257, 2079-2087, 2009.

Asner, G. P., Anderson, C. B., Martin, R. E., Knapp, D. E., Tupayachi, R., Sinca, F., and Malhi, Y.: Landscape=scale changes in forest structure and functional traits along an Andesto-Amazon elevation gradient, Biogeosciences, 11, 843-856, doi:10.5194/bg-11-843-2014, 2014.

Beer, C., Reichstein, M., Tomelleri, E., Ciais, P., Jung, M., Carvalhais, N., Rodenbeck, C., Arain, M. A., Baldocchi, D., Bonan, G. B., Bondeau, A., Cescatti, A., Lasslop, G., Lindroth, A., Lomas, M., Luyssaert, S., Margolis, H., Oleson, K. W., Roupsard, O., Veenendaal, E., Viovy, N., Williams, C., Woodward, F. I., and Papale, D.: Terrestrial gross carbon dioxide uptake: Global distribution and covariation with climate, Science, 329, 834-838, 2010.

Brookes, P. C., Landman, A., Pruden, G., and Jenkinson, D. S.: Chloroform fumigation and the release of soil-nitrogen - a rapid direct extraction method to measure microbial biomass nitrogen in soil, Soil Biol. Biochem., 17, 837-842, 1985.

Bruijnzeel, L. A., Scatena, F. N., and Hamilton, L. S.: Tropical Montane Cloud Forests, Cambridge University Press, Cambridge, UK, 2011.

Carlotto, V., Gil, W., Cardenas, J., and Chavez, R.: Mapa Geologico del Cuadrangula de Calca (27-s), Ministerio de engergia y minas Instituto geologico minero y metalurgico (INGEMMET), Republica del Peru, 1996.

Clark, K. E., Hilton, R. G., West, A. J., Malhi, Y., Gröcke, D. R., Bryant, C. L., Ascough, P. L., Robles Caceres, A., and New, M.: New views on "old" carbon in the Amazon River: Insight from the source of organic carbon eroded from the Peruvian Andes, Geochem. Geophys. Geosys., 14, 1644-1659, 2013.
Cleveland, C. C. and Liptzin, D.: C: N : P stoichiometry in soil: is there a "Redfield ratio" for the microbial biomass?, Biogeochemistry, 85, 235-252, 2007.

Cleveland, C. C. and Townsend, A. R.: Nutrient additions to a tropical rain forest drive substantial soil carbon dioxide losses to the atmosphere, P. Natl. Acad. Sci. USA, 103, 10316-10321, 2006.

Cleveland, C. C., Townsend, A. R., and Schmidt, S. K.: Phosphorus limitation of microbial processes in moist tropical forests: Evidence from short-term laboratory incubations and field studies, Ecosystems, 5, 680-691, 2002.

Cleveland, C. C., Reed, S. C., and Townsend, A. R.: Nutrient regulation of organic matter decomposition in a tropical rain forest, Ecology, 87, 492-503, 2006.

Cleveland, C. C., Townsend, A. R., Taylor, P., Alvarez-Clare, S., Bustamante, M. M., Chuyong, G., Dobrowski, S. Z., Grierson, P., Harms, K. E., Houlton, B. Z., Marklein, A., Parton, W., Porder, S., Reed, S. C., Sierra, C. A., Silver, W. L., Tanner, E. V., and Wieder, W. R.: Relationships among net primary productivity, nutrients and climate in tropical rain forest: a pan-tropical analysis, Ecol. Lett., 14, 939-947, 2011.

Corre, M. D., Veldkamp, E., Arnold, J., and Wright, S. J.: Impact of elevated $\mathrm{N}$ input on soil $\mathrm{N}$ cycling and losses in old-growth lowland and montane forests in Panama, Ecology, 91, 1715-1729, 2010.

Cusack, D. F., Silver, W. L., Torn, M. S., Burton, S. D., and Firestone, M. K.: Changes in microbial community characteristics and soil organic matter with nitrogen additions in two tropical forests, Ecology, 92, 621-632, 2011 a.

Cusack, D. F., Silver, W. L., Torn, M. S., and McDowell, W. H.: Effects of nitrogen additions on above- and belowground carbon dynamics in two tropical forests, Biogeochemistry, 104, 203225, $2011 b$.

Elser, J. J., Acharya, K., Kyle, M., Cotner, J., Makino, W., Markow, T., Watts, T., Hobbie, S., Fagan, W., Schade, J., Hood, J., and Sterner, R. W.: Growth rate-stoichiometry couplings in diverse biota, Ecol. Lett., 6, 936-943, 2003.

Elser, J. J., Bracken, M. E., Cleland, E. E., Gruner, D. S., Harpole, W. S., Hillebrand, H., Ngai, J. T., Seabloom, E. W., Shurin, J. B., and Smith, J. E.: Global analysis of nitrogen and phosphorus limitation of primary producers in freshwater, marine and terrestrial ecosystems, Ecol. Lett., 10, 1135-1142, 2007.

Elser, J. J., Andersen, T., Baron, J. S., Bergstrom, A. K., Jansson, M., Kyle, M., Nydick, K. R., Steger, L., and Hessen, D. O.: Shifts in lake $\mathrm{N}: \mathrm{P}$ stoichiometry and nutrient limitation driven by atmospheric nitrogen deposition, Science, 326, 835-837, 2009.

Feeley, K. J., Silman, M. R., Bush, M. B., Farfan, W., Cabrera, K. G., Malhi, Y., Meir, P., Revilla, N. S., Quisiyupanqui, M. N. R., and Saatchi, S.: Upslope migration of Andean trees, J. Biogeogr., 38, 783-791, 2011.

Fisher, J. B., Malhi, Y., Torres, I. C., Metcalfe, D. B., van de Weg, M. J., Meir, P., Silva-Espejo, J. E., and Huasco, W. H.: Nutrient limitation in rainforests and cloud forests along a 3,000-m elevation gradient in the Peruvian Andes, Oecologia, 172, 889-902, 2013.

Garzione, C. N., Hoke, G. D., Libarkin, J. C., Withers, S., MacFadden, B., Eiler, J., Ghosh, P., and Mulch, A.: Rise of the Andes, Science, 320, 1304-1307, 2008.

Girardin, C. A. J., Malhi, Y., Aragao, L. E. O. C., Mamani, M., Huaraca Huasco, W., Durand, L., Feeley, K. J., Rapp, J., Silva- 
Espejo, J. E., Silman, M., Salinas, N., and Whittaker, R. J.: Net primary productivity allocation and cycling of carbon along a tropical forest elevational transect in the Peruvian Andes, Glob. Change Biol., 16, 3176-3192, 2010.

Hall, S. J. and Matson, P. A.: Nutrient status of tropical rain forests influences soil $\mathrm{N}$ dynamics after $\mathrm{N}$ additions, Ecol. Monogr., 73, 107-129, 2003.

Hartman, W. H. and Richardson, C. J.: Differential nutrient limitation of soil microbial biomass and metabolic quotients $q \mathrm{CO}_{2}$ : Is there a biological stoichiometry of soil microbes?, Plos One, 8 , e57127, 2013.

Hattenschwiler, S., Coq, S., Barantal, S., and Handa, I. T.: Leaf traits and decomposition in tropical rainforests: revisiting some commonly held views and towards a new hypothesis, New Phytol., 189, 950-965, 2011.

Hedin, L. O., Brookshire, E. N. J., Menge, D. N. L., and Barron, A. R.: The nitrogen paradox in tropical forest ecosystems, Annu. Rev. Ecol. Evol. S., 40, 613-635, 2009.

Hietz, P., Turner, B. L., Wanek, W., Richter, A., Nock, C. A., and Wright, S. J.: Long-term change in the nitrogen cycle of tropical forests, Science, 334, 664-666, 2011.

Jenkinson, D. S., Brookes, P. C., and Powlson, D. S.: Measuring soil microbial biomass, Soil Biol. Biochem., 36, 5-7, 2004.

Kaspari, M., Garcia, M. N., Harms, K. E., Santana, M., Wright, S. J., and Yavitt, J. B.: Multiple nutrients limit litterfall and decomposition in a tropical forest, Ecol. Lett., 11, 35-43, 2008.

Kaspari, M., Yanoviak, S. P., Dudley, R., Yuan, M., and Clay, N. A.: Sodium shortage as a constraint on the carbon cycle in an inland tropical rainforest, P. Natl. Acad. Sci. USA, 106, 19405-19409, 2009.

Körner, C.: The use of "altitude" in ecological research, Trends Ecol. Evol., 22, 569-574, 2007.

Kouno, K., Tuchiya, Y., and Ando, T.: Measurement of soil microbial biomass phosphorus by an anion-exchange membrane method, Soil Biol. Biochem., 27, 1353-1357, 1995.

Li, Y. Q., Xu, M., and Zou, X. M.: Effects of nutrient additions on ecosystem carbon cycle in a Puerto Rican tropical wet forest, Glob. Change Biol., 12, 284-293, 2006.

Loladze, I. and Elser, J. J.: The origins of the Redfield nitrogento-phosphorus ratio are in a homoeostatic protein-to-rRNA ratio, Ecol. Lett., 14, 244-250, 2011.

Makino, W., Cotner, J. B., Sterner, R. W., and Elser, J. J.: Are bacteria more like plants or animals? Growth rate and resource dependence of bacterial C : N : P stoichiometry, Funct. Ecol., 17, 121-130, 2003.

Marrs, R. H., Proctor, J., Heaney, A., and Mountford, M. D.: Changes in soil nitrogen mineralization and nitrification along an altitudinal transect in tropical rain forest in Costa-Rica, J. Ecol., 76, 466-482, 1988.

McGroddy, M. E., Daufresne, T., and Hedin, L. O.: Scaling of C : N : P stoichiometry in forests worldwide: Implications of terrestrial redfield-type ratios, Ecology, 85, 2390-2401, 2004.

Mirmanto, E., Proctor, J., Green, J., Nagy, L., and Suriantata: Effects of nitrogen and phosphorus fertilization in a lowland evergreen rainforest, Philos. T. R. Soc. B, 354, 1825-1829, 1999.

Nottingham, A. T., Whitaker, J., Turner, B. L., Salinas, N., Zimmermann, M., Malhi, Y., and Meir, P.: Climate Warming and Soil Carbon in Tropical Forests: Insights from an Elevation Gradient in the P eruvian Andes, Bioscience, 65, 906-921, 2015.
Olander, L. P. and Vitousek, P. M.: Regulation of soil phosphatase and chitinase activity by $\mathrm{N}$ and $\mathrm{P}$ availability, Biogeochemistry, 49, 175-190, 2000.

Pan, Y., Birdsey, R. A., Fang, J., Houghton, R., Kauppi, P. E., Kurz, W. A., Phillips, O. L., Shvidenko, A., Lewis, S. L., Canadell, J. G., Ciais, P., Jackson, R. B., Pacala, S. W., McGuire, A. D., Piao, S., Rautiainen, A., Sitch, S., and Hayes, D.: A large and persistent carbon sink in the world's forests, Science, 333, 988-993, 2011.

Porder, S. and Hilley, G. E.: Linking chronosequences with the rest of the world: predicting soil phosphorus content in denuding landscapes, Biogeochemistry, 102, 153-166, 2010.

Quesada, C. A., Lloyd, J., Schwarz, M., Patiño, S., Baker, T. R., Czimczik, C., Fyllas, N. M., Martinelli, L., Nardoto, G. B., Schmerler, J., Santos, A. J. B., Hodnett, M. G., Herrera, R., Luizão, F. J., Arneth, A., Lloyd, G., Dezzeo, N., Hilke, I., Kuhlmann, I., Raessler, M., Brand, W. A., Geilmann, H., Moraes Filho, J. O., Carvalho, F. P., Araujo Filho, R. N., Chaves, J. E., Cruz Junior, O. F., Pimentel, T. P., and Paiva, R.: Variations in chemical and physical properties of Amazon forest soils in relation to their genesis, Biogeosciences, 7, 1515-1541, doi:10.5194/bg-7-15152010, 2010.

Rapp, J. M. and Silman, M. R.: Diurnal, seasonal, and altitudinal trends in microclimate across a tropical montane cloud forest, Clim. Res., 55, 17-32, 2012.

Redfield, A. C.: The biological control of chemical factors in the environment, Am. Sci., 46, 205-221, 1958.

Reed, S. C., Townsend, A. R., Taylor, P. G., and Cleveland, C. C.: Phosphorus cycling in tropical forests growing on highly weathered soils, Soil Biol., 26, 339-369, 2011.

Ross, D. J.: Influence of sieve mesh size on estimates of microbial carbon and nitrogen by fumigation extraction procedures in soils under pasture, Soil Biol. Biochem., 24, 343-350, 1992.

Santiago, L. S., Wright, S. J., Harms, K. E., Yavitt, J. B., Korine, C., Garcia, M. N., and Turner, B. L.: Tropical tree seedling growth responses to nitrogen, phosphorus and potassium addition, J. Ecol., 100, 309-316, 2012.

Sinsabaugh, R. L. and Moorhead, D. L.: Resource-allocation to extracellular enzyme-production - a model for nitrogen and phosphorus control of litter decomposition, Soil Biol. Biochem., 26, 1305-1311, 1994.

Sinsabaugh, R. L., Lauber, C. L., Weintraub, M. N., Ahmed, B., Allison, S. D., Crenshaw, C., Contosta, A. R., Cusack, D., Frey, S., Gallo, M. E., Gartner, T. B., Hobbie, S. E., Holland, K., Keeler, B. L., Powers, J. S., Stursova, M., Takacs-Vesbach, C., Waldrop, M. P., Wallenstein, M. D., Zak, D. R., and Zeglin, L. H.: Stoichiometry of soil enzyme activity at global scale, Ecol. Lett., 11, 1252-1264, 2008.

Sinsabaugh, R. L., Hill, B. H., and Shah, J. J. F.: Ecoenzymatic stoichiometry of microbial organic nutrient acquisition in soil and sediment, Nature, 462, 795-798, 2009.

Six, J., Frey, S. D., Thiet, R. K., and Batten, K. M.: Bacterial and fungal contributions to carbon sequestration in agroecosystems, Soil Sci. Soc. Am. J., 70, 555-569, 2006.

Sparling, G. P., Feltham, C. W., Reynolds, J., West, A. W., and Singleton, P.: Estimation of soil microbial $\mathrm{C}$ by a fumigation extraction method - use on soils of high organic-matter content, and a reassessment of the Kec-factor, Soil Biol. Biochem., 22, 301307, 1990. 
Sterner, R. W. and Elser, J. J.: Ecological stoichiometry: The biology of elements from molecules to biosphere, Princeton University Press, Princeton, N.J., 2002.

Sundareshwar, P. V., Morris, J. T., Koepfler, E. K., and Fornwalt, B.: Phosphorus limitation of coastal ecosystem processes, Science, 299, 563-565, 2003.

Tabatabai, M. A.: Soil enzymes, in: Methods of soil analysis. Part 2. Microbiological and biochemical properties, edited by: Weaver, R., Angle, S., Bottomley, P., Bezdiecek, D., Smith, S., Tabatabai, A., Wollum, A., Mickelson S. H., and Bigham J. M., SSSA, Madison, WI, 1994.

Tanner, E. V. J., Kapos, V., and Franco, W.: Nitrogen and phosphorus fertilization effects on Venezuelan montane forest trunk growth and litterfall, Ecology, 73, 78-86, 1992.

Tanner, E. V. J., Vitousek, P. M., and Cuevas, E.: Experimental investigation of nutrient limitation of forest growth on wet tropical mountains, Ecology, 79, 10-22, 1998.

Templer, P. H., Lovett, G. M., Weathers, K. C., Findlay, S. E., and Dawson, T. E.: Influence of tree species on forest nitrogen retention in the Catskill Mountains, New York, USA, Ecosystems, 8, $1-16,2005$.

Townsend, A. R., Cleveland, C. C., Houlton, B. Z., Alden, C. B., and White, J. W. C.: Multi-element regulation of the tropical forest carbon cycle, Front. Ecol. Environ., 9, 9-17, 2011.

Treseder, K. K. and Vitousek, P. M.: Effects of soil nutrient availability on investment in acquisition of $\mathrm{N}$ and $\mathrm{P}$ in Hawaiian rain forests, Ecology, 82, 946-954, 2001.

Turner, B. L. and Romero, T. E.: Short-term changes in extractable inorganic nutrients during storage of tropical rain forest soils, Soil Sci. Soc. Am. J., 73, 1972-1979, 2010.

Turner, B. L. and Wright, S. J.: The response of microbial biomass and hydrolytic enzymes to a decade of nitrogen, phosphorus, and potassium addition in a lowland tropical rain forest, Biogeochemistry, 117, 115-130, 2014.

Turner, B. L., Lambers, H., Condron, L. M., Cramer, M. D., Leake, J. R., Richardson, A. E., and Smith, S. E.: Soil microbial biomass and the fate of phosphorus during long-term ecosystem development, Plant Soil, 367, 225-234, 2013.

van de Weg, M., Meir, P., Williams, M., Girardin, C., Malhi, Y., Silva-Espejo, J., and Grace, J.: Gross Primary Productivity of a High Elevation Tropical Montane Cloud Forest, Ecosystems, 17, 751-764, 2014

van de Weg, M. J., Meir, P., Grace, J., and Atkin, O. K.: Altitudinal variation in leaf mass per unit area, leaf tissue density and foliar nitrogen and phosphorus content along an Amazon-Andes gradient in Peru, Plant. Ecol. Divers., 2, 243-254, 2009.
Vance, E. D., Brookes, P. C., and Jenkinson, D. S.: An extraction method for measuring soil microbial biomass-C, Soil Biol. Biochem., 19, 703-707, 1987.

Vitousek, P. M.: Litterfall, nutrient cycling, and nutrient limitation in tropical forests, Ecology, 65, 285-298, 1984.

Vitousek, P. M. and Sanford, R. L.: Nutrient cycling in moist tropical forest, Annu. Rev. Ecol. Syst., 17, 137-167, 1986.

Vitousek, P. M., Porder, S., Houlton, B. Z., and Chadwick, O. A.: Terrestrial phosphorus limitation: mechanisms, implications, and nitrogen-phosphorus interactions, Ecol. Appl., 20, 5-15, 2010.

Wardle, D. A.: A comparative-assessment of factors which Influence microbial biomass carbon and nitrogen levels in soil, Biol. Rev., 67, 321-358, 1992.

Wardle, D. A., Bardgett, R. D., Klironomos, J. N., Setala, H., van der Putten, W. H., and Wall, D. H.: Ecological linkages between aboveground and belowground biota, Science, 304, 1629-1633, 2004.

Waring, B. G.: A meta-analysis of climatic and chemical controls on leaf litter decay rates in tropical forests, Ecosystems, 15, 9991009, 2012.

Whitaker, J., Ostle, N., Nottingham, A. T., Ccahuana, A., Salinas, N., Bardgett, R. D., Meir, P., and McNamara, N. P.: Microbial community composition explains soil respiration responses to changing carbon inputs along an Andes-to-Amazon elevation gradient, J. Ecol., 102, 1058-1071, 2014.

Wolf, K., Veldkamp, E., Homeier, J., and Martinson, G. O.: Nitrogen availability links forest productivity, soil nitrous oxide and nitric oxide fluxes of a tropical montane forest in southern Ecuador, Global Biogeochem. Cy., 25, GB4009, doi:10.1029/2010gb003876, 2011.

Wright, S. J., Yavitt, J. B., Wurzburger, N., Turner, B. L., Tanner, E. V. J., Sayer, E. J., Santiago, L. S., Kaspari, M., Hedin, L. O., Harms, K. E., Garcia, M. N., and Corre, M. D.: Potassium, phosphorus, or nitrogen limit root allocation, tree growth, or litter production in a lowland tropical forest, Ecology, 92, 1616-1625, 2011.

Zimmermann, M., Meir, P., Bird, M. I., Malhi, Y., and Ccahuana, A. J. Q.: Temporal variation and climate dependence of soil respiration and its components along a $3000 \mathrm{~m}$ altitudinal tropical forest gradient, Global Biogeochem. Cy., 24, GB4012, doi:10.1029/2010gb003787, 2010. 